Article

\title{
Profiling of the Bacterial Microbiota along the Murine Alimentary Tract
}

\author{
Ramiro Vilchez-Vargas ${ }^{1}$, Franz Salm ${ }^{2}$, Eva B. Znalesniak ${ }^{2}$, Katharina Haupenthal ${ }^{2}$, Denny Schanze ${ }^{3} \mathbb{D}$, \\ Martin Zenker ${ }^{3}$, Alexander Link ${ }^{1, * \mathbb{D}}$ and Werner Hoffmann ${ }^{2, *(\mathbb{D})}$
}

1 Department of Gastroenterology, Hepatology, and Infectiology, Otto-von-Guericke University Magdeburg, Leipziger Str. 44, 39120 Magdeburg, Germany; ramiro.vilchez@med.ovgu.de

2 Institute of Molecular Biology and Medicinal Chemistry, Otto-von-Guericke University Magdeburg, Leipziger Str. 44, 39120 Magdeburg, Germany; franz.salm@gmx.de (F.S.); eva.znalesniak@med.ovgu.de (E.B.Z.); katharina.haupenthal@med.ovgu.de (K.H.)

3 Institute of Human Genetics, Otto-von-Guericke University Magdeburg, Leipziger Str. 44 39120 Magdeburg, Germany; denny.schanze@med.ovgu.de (D.S.); martin.zenker@med.ovgu.de (M.Z.)

* Correspondence: alexander.link@med.ovgu.de (A.L.); werner.hoffmann@med.ovgu.de (W.H.)

check for updates

Citation: Vilchez-Vargas, R.; Salm, F.; Znalesniak, E.B.; Haupenthal, K.; Schanze, D.; Zenker, M.; Link, A.; Hoffmann, W. Profiling of the Bacterial Microbiota along the Murine Alimentary Tract. Int. J. Mol. Sci. 2022, 23, 1783. https://doi.org/ $10.3390 /$ ijms 23031783

Academic Editor: Rustam I. Aminov

Received: 17 December 2021

Accepted: 28 January 2022

Published: 4 February 2022

Publisher's Note: MDPI stays neutral with regard to jurisdictional claims in published maps and institutional affiliations.

Copyright: (C) 2022 by the authors. Licensee MDPI, Basel, Switzerland. This article is an open access article distributed under the terms and conditions of the Creative Commons Attribution (CC BY) license (https:// creativecommons.org/licenses/by/ $4.0 /)$.

\begin{abstract}
Here, the spatial distribution of the bacterial flora along the murine alimentary tract was evaluated using high throughput sequencing in wild-type and Tff3-deficient (Tff3 $\left.{ }^{\mathrm{KO}}\right)$ animals. Loss of Tff3 was linked to increased dextran sodium sulfate-induced colitis. This systematic study shows the results of 13 different regions from the esophagus to the rectum. The number of bacterial species (richness) increased from the esophagus to the rectum, from 50 to 200, respectively. Additionally, the bacterial community structure changed continuously; the highest changes were between the upper/middle and lower gastrointestinal compartments when comparing adjacent regions. Lactobacillus was the major colonizer in the upper/middle gastrointestinal tract, especially in the esophagus and stomach. From the caecum, a drastic diminution of Lactobacillus occurred, while members of Lachnospiraceae significantly increased. A significant change occurred in the bacterial community between the ascending and the transverse colon with Bacteroidetes being the major colonizers with relative constant abundance until the rectum. Interestingly, wild-type and $T f f 3{ }^{\mathrm{KO}}$ animals did not show significant differences in their bacterial communities, suggesting that Tff 3 is not involved in alterations of intraluminal or adhesive microbiota but is obviously important for mucosal protection, e.g., of the sensitive stem cells in the colonic crypts probably by a mucus plume.
\end{abstract}

Keywords: microbiota; gut bacteria; gut microbiome; trefoil factor; TFF3; mucus; stomach; intestine; esophagus; colitis

\section{Introduction}

Mucous epithelia mainly cover the inner surfaces of the body and are essential for vital interactions with our environment (respiration, nutrition, reproduction, visual and auditory systems). As a consequence, the various mucosae represent a preferred location for microbiota. The microbial composition varies dramatically at different body sites in healthy humans [1]. Within the last decade, it has become increasingly clear that the microbiota has severe and diverse influences on health and disease, particularly in the gut [2]. On the one hand, diet is an important factor shaping microbial composition [3-6]. On the other hand, the gut microbiome impacts obesity and metabolic dysfunctions, such as metabolic syndrome, type 2 diabetes, and inflammation, as well as neurological disorders [7-9]. For example, bacterial metabolites (postbiotics) regulate gene expression, e.g., of mucins [6]. Furthermore, there are molecular links between microbiota and genotoxic events leading to various types of human cancers $[10,11]$. Thus, it is of increasing clinical interest that fecal microbiota transplants show therapeutic effects and there are many possi- 
ble applications, such as inflammatory bowel disease, metabolic syndrome, obesity, autism, multiple sclerosis, Parkinson's disease, and even cancer [6,12].

Only the development of culture-independent methods allowed a more complete identification of the complex microbiota. In the stomach, five major phyla (divisions) of bacteria were detected, i.e., Firmicutes, Bacteroidetes, Actinobacteria, Fusobacteria and Proteobacteria $[13,14]$; whereas the human distal gut microbiota is typically dominated by two bacterial phyla, i.e., the Firmicutes and the Bacteroidetes, and one member of the Archaea $[15,16]$. Generally, the majority of the microbes reside in the colon.

An essential element of the host-microbiota symbiosis is the mucus barrier, which typically covers mucous epithelia [13,17-19]. Characteristic components of these barriers are gel-forming mucins and their composition varies for each mucosa fulfilling a special physiological function [17]. Further components are various ions, and a complex mixture of additional proteins, such as immunoglobulins, trefoil factor family (TFF) peptides, gastrokines, IgG-Fc-binding protein (FCGBP), DMBT1/gp340, galectins, defensins, and lysozyme $[17,20]$. In addition, also the physical structure of the mucus layer varies along the gastrointestinal tract. A two-layered structure is found in the stomach and colon; whereas in the small intestine, the mucus layer is simpler [21]. On the one hand, the mucus layer is the first-line defense of the epithelium, which interacts with the immune system [22]. On the other hand, a dense microbial community is embedded in the mucus layer resembling a biofilm [19]. For example, colonic mucus encapsulates the fecal material including the microbiota, which direct their own encapsulation [23]. Upon induction of mucus defects, the bacterial loads increased, particularly in areas between fecal pellets, leading to inflammation [23,24].

In the past, mice were intensely used as a model system for studying various physiological effects of microbiota [19,25-27]. Our group has recently provided systematic data on microbial distribution through the human gastrointestinal (GI) tract [28]. However, the data are limited by an endoscopic biopsy collection, and potential bacterial cross-contamination cannot be excluded, in particular esophagus versus stomach versus duodenum or ileum versus colon versus rectum. Thus, we aimed to systematically analyze the bacterial microbiota along the alimentary tract of mice, which would allow to exclude potential endoscopy-related contamination.

In addition, the microbiota was also analyzed in Tff3-deficient $\left(T f f 3^{\mathrm{KO}}\right)$ mice. These mice were chosen as they react much more sensitively in the dextran sulfate sodium (DSS)-induced colitis model, probably due to an intestinal barrier defect $[29,30]$. In the DSS model, the thickness of the inner mucus layer decreases and becomes permeable to bacteria [31]. TFF3 is a member of the trefoil factor family [32,33] and forms a disulfidelinked heterodimer with FCGBP $[34,35]$. TFF3, together with FCGBP and the mucin MUC2, is predominantly secreted from intestinal goblet cells (GCs) [34,36,37]. Minor amounts of TFF3 and FCGBP are synthesized along the alimentary tract, i.e., in labial and submandibular glands [38,39], in esophageal submucosal glands and the gastric cardia [40], as well as in the gastric antrum [41-43]. FCGBP and TFF3-FCGBP are considered components of the mucosal innate immune defense regulating pathogen attachment and clearing of microorganisms $[32,44,45]$. This may be in connection with DMBT1/gp340, as the latter also binds to TFF3 [46]. DMBT1/gp340 is highest expressed in the intestine (by enterocytes [47]) and is identical to salivary agglutinin, which aggregates Streptococcus and agglutinates influenza A virus $[48,49]$.

In the present study, we systematically characterized the bacterial communities from 13 different locations along the alimentary/GI tract from wild-type and Tff3 $3^{\mathrm{KO}}$ mice with the aim of testing whether a lack of Tff3 affects the composition of the microbiota, particularly in the intestine. This investigation was also designed to establish a detailed topographical distribution of the bacterial microbiota throughout the entire murine GI tract, which is a prerequisite to studying bacterial communities in different mouse models, such as probiotic trials. Of note, probiotics upregulate Tff1 and Tff 2 in the murine stomach [50]. 


\section{Results}

Bacterial communities were analyzed throughout the alimentary tract of nine wildtype and nine $T f f 3^{\mathrm{KO}}$ mice. The following anatomical locations were investigated: esophagus; forestomach, gastric corpus, gastric antrum; proximal and distal parts of the duodenum, respectively; the middle section of the jejunum; distal ileum; the middle part of the caecum; proximal (ascending), medial (transverse), and distal (descending) colon; rectum. Generally, the microbiota in the luminal content, as well as the mucus, were analyzed altogether without differentiation. After resampling to the minimum sequencing depth of 3172 reads per sample, a total of 624,884 sequences were retrieved from 197 samples successfully sequenced (37 samples, mainly from the lower GI tract, did not yield any PCR product). A total of 4560 phylotypes were detected in the whole cohort, 4297 phylotypes were assigned to a phylum (263 remained as unclassified bacteria), 3492 were assigned to family and 2453 were assigned to the genus (Supplementary Table S1: raw data with the phyloptypes sequences).

\subsection{Overall Bacterial Communities in Wild-Type and $\mathrm{Tff}^{\mathrm{KO}}$ Mice}

In both groups of mice, there was an increase in the species richness from the esophagus to the rectum. For example, in the esophagus the species richness was about 50; in the stomach, duodenum, jejunum and ileum it was roughly 100; whereas in the caecum, colon and rectum it increased to about 200. In line with this, the diversity also increased throughout the gastrointestinal tract and reached a maximum in the distal part of the intestine, as measured by the Simpson index (Figure 1).
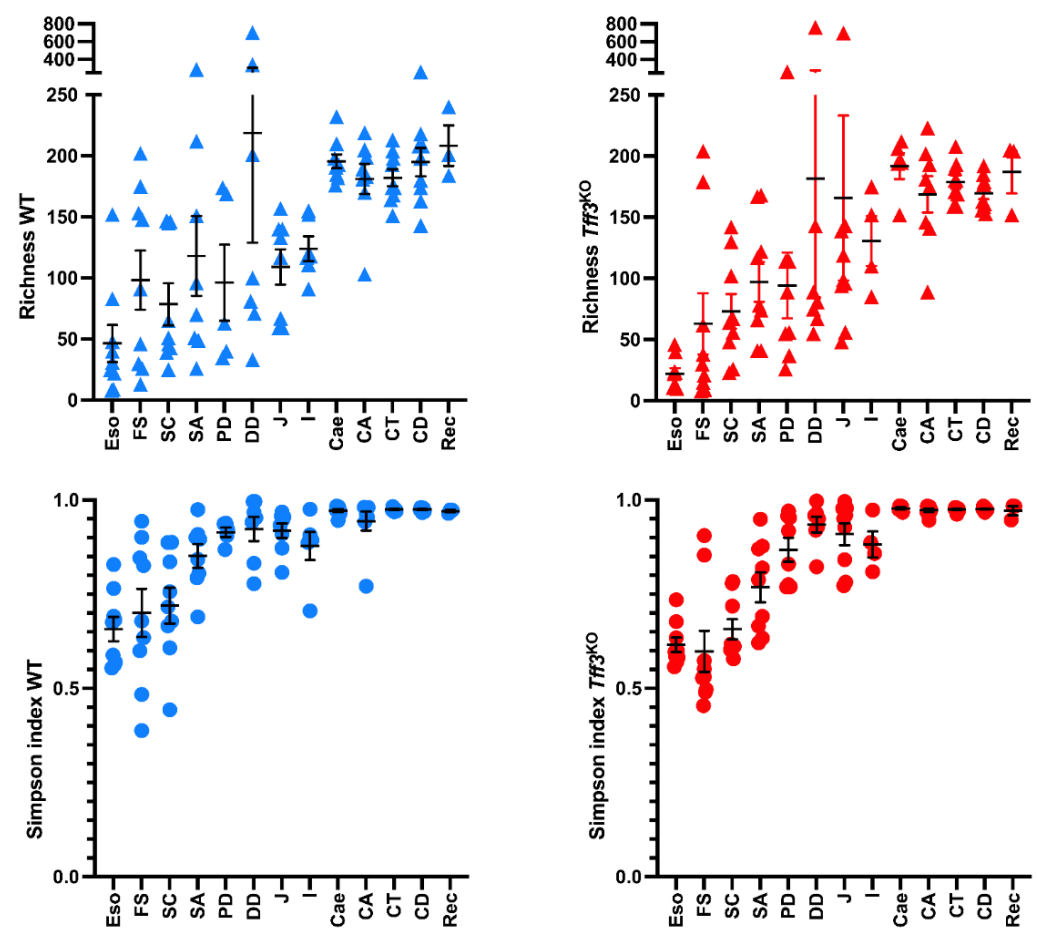

Figure 1. Richness (top) and Simpson index (down) in wild-type (left panel, in blue) and Tff3 ${ }^{\mathrm{KO}}$ (right panel, in red) mice through the gastrointestinal tract; esophagus (Eso), forestomach (FS), stomach corpus (SC), stomach antrum (SA), proximal duodenum (PD), distal duodenum (DD), jejunum (J), ileum (I), caecum (Cae), ascending colon (CA), transverse colon (CT), descending colon (CD), and rectum $(\mathrm{Rec})$.

Both groups of mice (wild-type and $\mathrm{Tff} 3^{\mathrm{KO}}$ ) did not show statistically significant differences with respect to the richness and diversity of the bacterial communities when the corresponding anatomical regions were compared pairwise ( $p$-value $>0.05$; data not 
illustrated). This suggests that the lack of Tff3 did not affect the relative abundance of bacterial taxa throughout the entire gastrointestinal tract.

\subsection{Spatial Analysis of the Bacterial Communities at the Genus Level}

The composition of the bacterial communities showed a clear shift between the ileum and the caecum in both the wild-type (Figure $2 ; p<0.001$ ) and Tff3 ${ }^{\mathrm{KO}}$ mice (Figure 3; $p<0.05$ in $T f f 3^{\mathrm{KO}}$ mice). The genus Lactobacillus was the major colonizer from the esophagus to the ileum, including the stomach, duodenum and jejunum. In the esophagus, Lactobacillus made up even more than $95 \%$ of the total bacterial communities. Particularly in the caecum and ascending colon, the relative abundance of the phylum Firmicutes dropped due to a drastic decrease in Lactobacillus $(p<0.01)$, the latter was replaced by other taxa belonging to Firmicutes (Lachnospiraceae, unclassified Clostridiales, and unclassified Ruminococcaceae) as well as Deferribacteres (Mucispirillum). Furthermore, members of the phylum Bacteroidetes (Alistipes) appeared and were the natural colonizers from the caecum to the rectum. Interestingly, PERMANOVA also revealed differences in the overall bacterial communities between the proximal (ascending) part of the colon and the transverse colon in both the wild-type (Figure 2) and Tff3 ${ }^{\mathrm{KO}}$ mice (Figure 3).
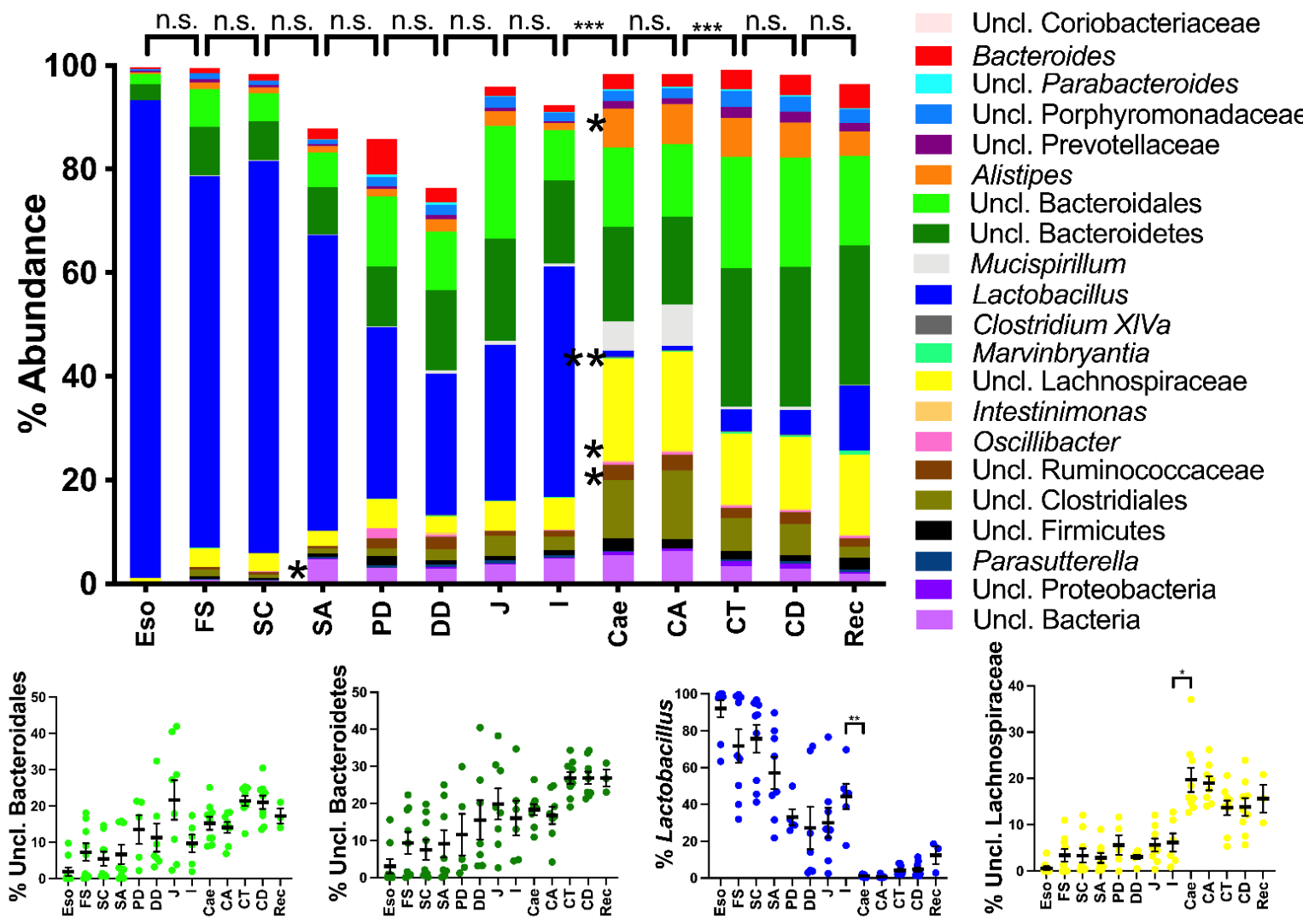

Figure 2. Relative abundance of bacterial microbiota along the alimentary tract of wild-type mice: esophagus (Eso), forestomach (FS), stomach corpus (SC), stomach antrum (SA), proximal duodenum (PD), distal duodenum (DD), jejunum (J), ileum (I), caecum (Cae), ascending colon (CA), transverse colon (CT), descending colon (CD), and rectum (Rec). Top: abundance of taxa detected at least in one region. Pairwise comparison between adjacent regions were calculated with PERMANOVA (n.s., no significant differences; ${ }^{* * *}$, significant differences). Bottom: abundance of taxa belonging to unclassified Bacteroidales (light green), unclassified Bacteroidetes (dark green), Lactobacillus (blue), and unclassified Lachnospiraceae (yellow) detected in the different regions. Differences between taxa in adjacent regions were calculated with Kruskal-Wallis test (Benjamin and Hochberg correction); $p<0.05:{ }^{*} ; p<0.01:^{* *} ; p<0.001{ }^{* * *}$. 


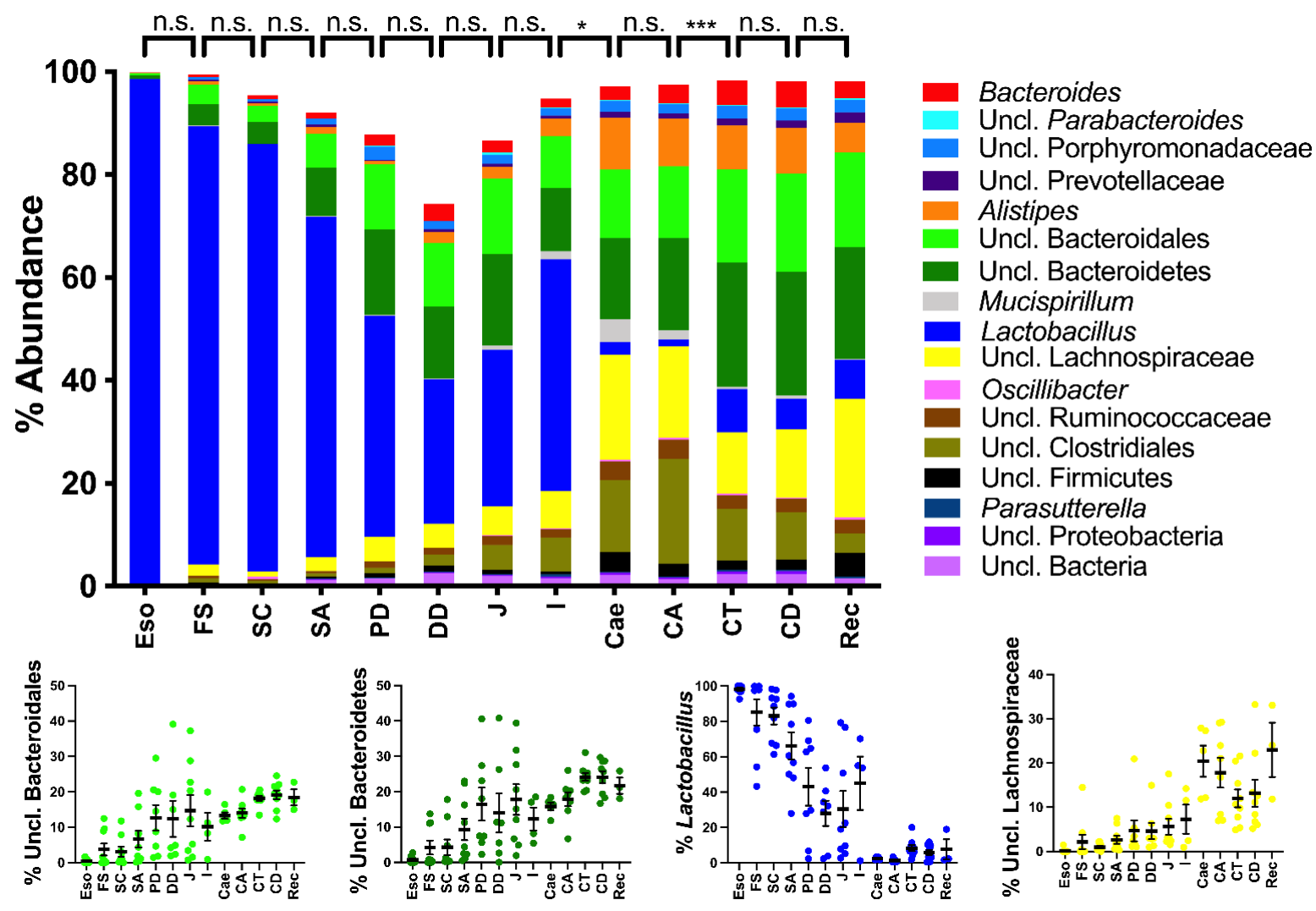

Figure 3. Relative abundance of bacterial microbiota along the alimentary tract of $T f f 3^{\mathrm{KO}}$ mice. For details see the legend of Figure 2.

Thus, three regions could be distinguished along the murine alimentary tract based on their bacterial communities. First, the esophagus, stomach, duodenum, jejunum, and ileum are dominated by Lactobacillus as the major colonizer with a progressive enrichment of the phylum Bacteroidetes (unclassified Bacteroidales and unclassified Bacteroidetes). The second region includes the caecum and the proximal (ascending) colon; whereas, the medial (transverse) colon, the distal (descending) colon and the rectum represent the third characteristic region.

As a consequence of the systematic sampling methodology, no statistically significant differences were found between adjacent regions, with the exception of ileum versus caecum and ascending versus transverse colon, as mentioned above. However, a systematic pairwise comparison of all the regions analyzed revealed that the bacterial communities progressively changed from the esophagus to the rectum (Supplementary Figure S1: pairwise comparisons). For instance, no differences between the esophagus and forestomach and corpus were detected, but bacterial communities between the esophagus and antrum were significantly different $(p<0.05)$; these differences became even more significant when comparing the esophagus with the duodenum or the other more distal regions $(p<0.001)$. Interestingly, pairwise comparisons between bacterial communities of the proximal duodenum and distal duodenum or jejunum or ileum did not show statistically significant differences. This indicates that the microbiota is stable from the proximal duodenum to the ileum; whereas, there is a statistically significant difference starting with the caecum (Supplementary Figure S1: pairwise comparisons).

Pairwise comparison of the corresponding anatomical regions of both groups of mice (wild-type and Tff $3^{\mathrm{KO}}$ ) did not reveal statistically significant differences in most regions with respect to the composition of the bacterial communities ( $p$-value $>0.05$; data not illustrated). The only exception was the ascending colon, which significantly differed at the genus level ( $p=0.02$; data not illustrated). This suggests that a lack of Tff3 did not affect the relative abundance of bacterial taxa in most regions of the alimentary tract. 


\subsection{Spatial Analysis of Lactobacillus Phylotypes}

When analyzing the sequences at the maximum level of resolution, i.e., the phylotype level, it became apparent that the bacterial communities of the esophagus, in both the wildtype and Tff3 ${ }^{\mathrm{KO}}$ mice clustered separately (Figure 4). A more detailed analysis revealed that the esophagus was colonized by phylotypes belonging to Lactobacillus murinus (Phy2, Phy21, Phy29 among others); whereas phylotypes belonging to Lactobacillus reuteri (Phy4, Phy7 and Phy19) and Lactobacillus gasseri/taiwanensis (Phy1, Phy11 and Phy59) were detected from the stomach to the ileum, L. murinus being almost absent in these regions (Figure 5). Clearly, three different regions could be distinguished in both the wild-type and Tff3 ${ }^{\mathrm{KO}}$ mice: first, the esophagus grouped separately and is characterized by the presence of L. murinus; second, a region spanning from the forestomach until the ileum, where L. gasseri/taiwanensis, $L$. reuteri, and only a little $L$. murinus were detectable; third, the lower GI tract from the caecum to the rectum, where L. murinus is missing and L. gasseri/taiwanensis and L. reuteri were hardly detectable. Here, after the ileum, the bacterial community showed the main profile change (Figure 5). Furthermore, there were no significant differences detectable between wild-type and Tff3 ${ }^{\mathrm{KO}}$ animals.

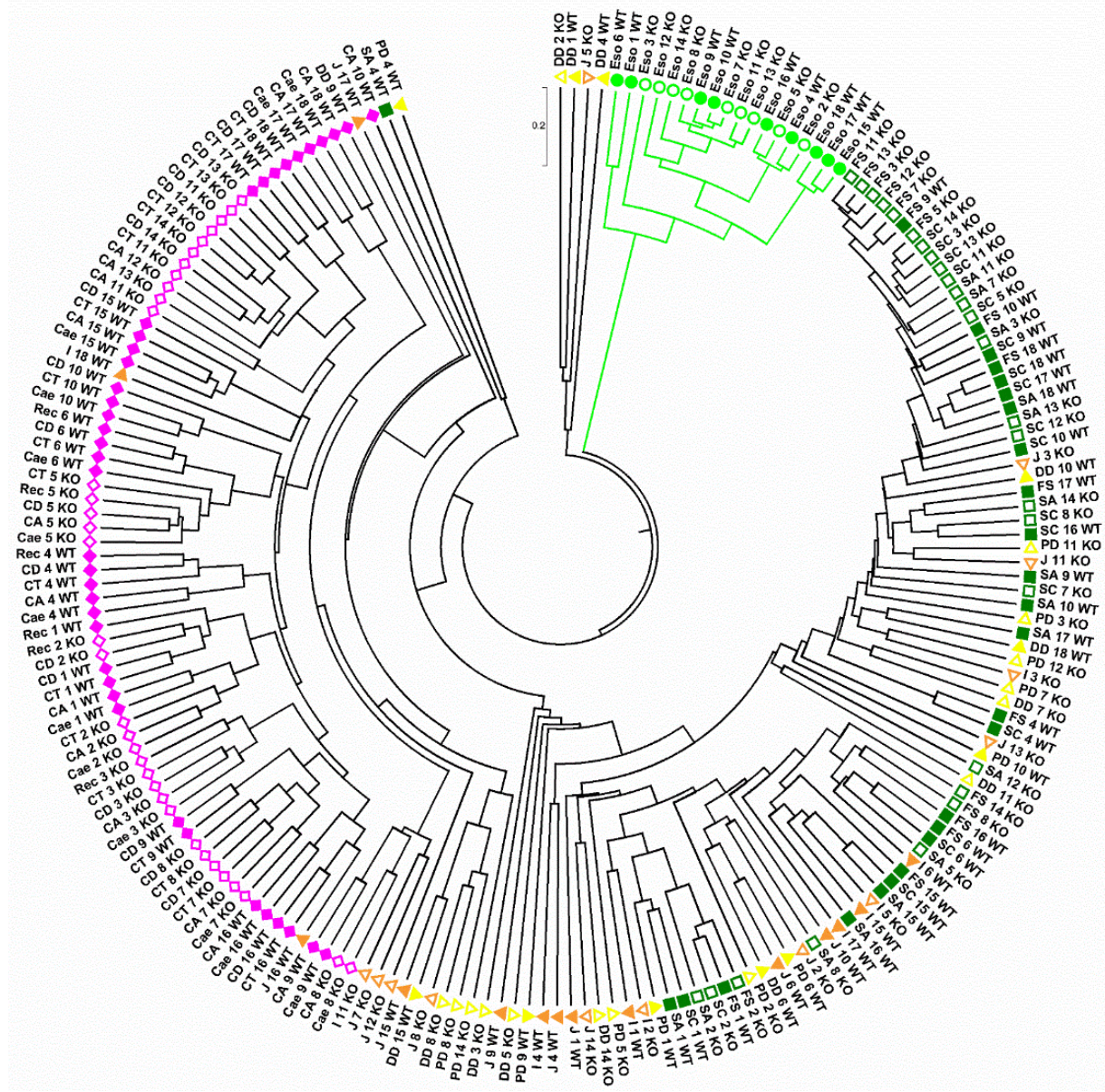

Figure 4. Group-average agglomerative hierarchical clustering of 197 samples, based on the global bacterial profiles at phylotype level and Bray-Curtis similarities. Each sample is termed by its anatomical region (for details see the legend of Figure 2), the number of the animal (from 1 to 18), and the mouse strain (wild-type or Tff $3^{\mathrm{KO}}$ ). 

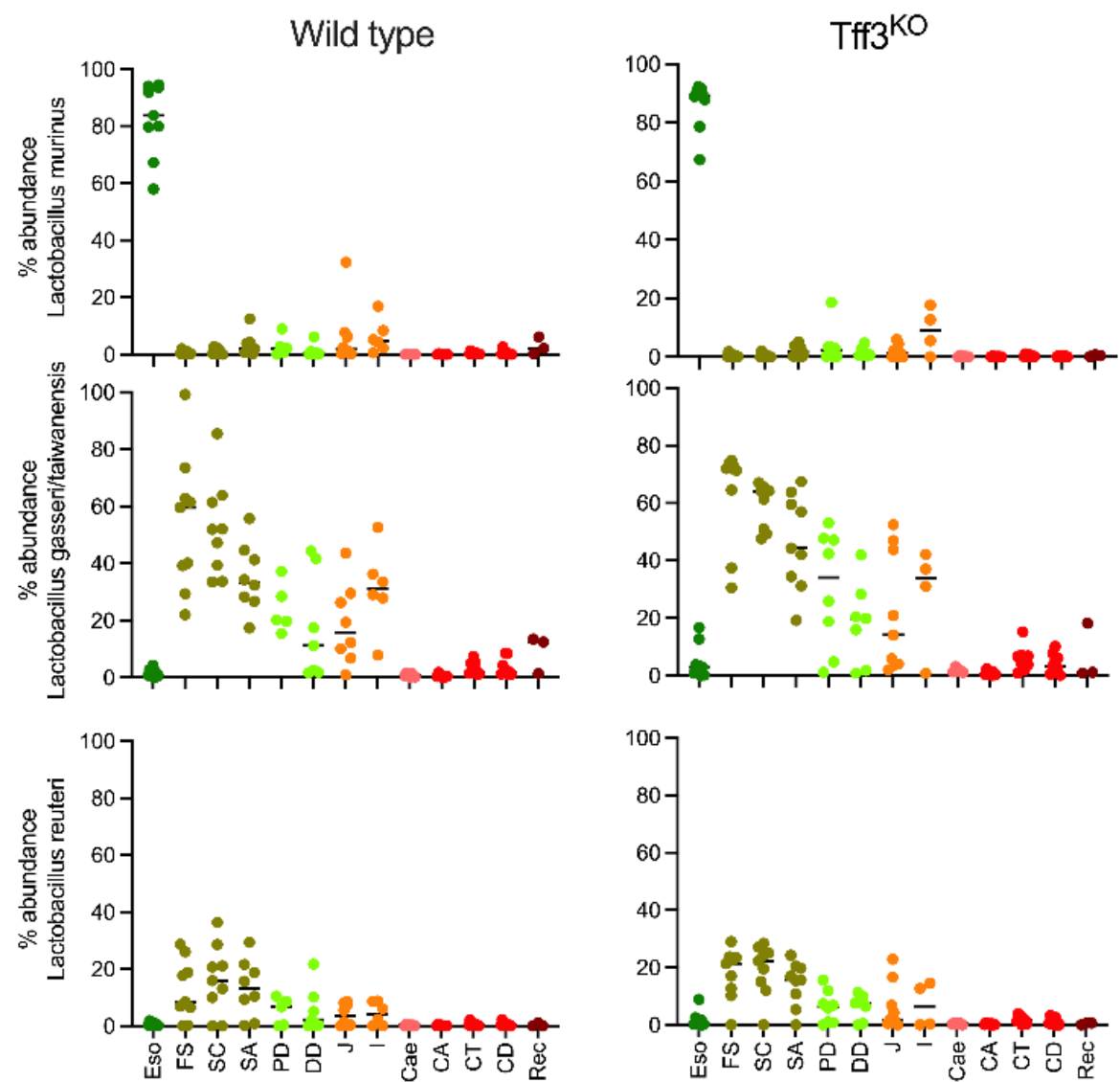

Figure 5. Relative abundance of phylotypes belonging to L. murinus, L. gasseri/taiwanensis and L. reuteri in each mouse and in each region; esophagus (Eso), forestomach (FS), stomach corpus (SC), stomach antrum (SA), proximal duodenum (PD), distal duodenum (DD), jejunum (J), ileum (I), caecum (Cae), ascending colon (CA), transverse colon (CT), descending colon (CD), and rectum (Rec).

\section{Discussion}

Here, we provide a comprehensive analysis of the bacterial communities in the murine alimentary tract by investigating 13 different anatomical regions from the esophagus to the rectum. Furthermore, Tff3 ${ }^{\mathrm{KO}}$ mice were compared with wild-type littermates as Tff3 ${ }^{\mathrm{KO}}$ mice react much more sensitively in the DSS colitis model, probably due to a defect in the colonic inner mucus barrier [29,30]. Here, Tff3 together with Tff3-Fcgbp is part of the mucosal innate immune defense, presumably regulating microbial attachment [32,44,45]. Of note, Tff3 expression is also linked to inflammation (for review, see [30]) and goblet cells are subject to complex immunomodulation. For example, Tff3 expression is reduced by the immune system after infection with Citrobacter rodentium, which is not observed in Rag $1^{\mathrm{KO}}$ mice [51]. This could be explained by a link of $\mathrm{T}$ lymphocytes and the homeostasis of intestinal epithelial cells by IL-7 [52]. Furthermore, Tff3 expression is induced by Toll-like receptor 2 (TLR2) activation by commensal bacteria, probably by an indirect mechanism [53].

\subsection{The Bacterial Communities Differ Significantly along the Murine Alimentary Tract}

Grossly, at the genus level, at least three regions were clearly distinguishable by their bacterial composition in both mouse strains investigated, with statistically significant differences between the distal ileum and the caecum, and also between the ascending colon and the transverse colon (Figures 2 and 3). This indicates that there are at least three different ecosystems, which clearly reflect distinct biochemical and physiological conditions. 


\subsubsection{The Upper Alimentary Tract}

The upper alimentary tract from the esophagus to the distal ileum is dominated by Lactobacillus with decreasing abundance; whereas unclassified Bacteroidetes, unclassified Bacteroidales, and unclassified Clostridiales gradually increase (Figures 2 and 3). Generally, the richness and the Simpson index continuously increased in the upper alimentary tract towards the ileum (Figure 1). For example, Lactobacillus contributes to about $95 \%$ of the bacterial abundance in the esophagus (Figures 2 and 3), which probably originates from the saliva. Remarkably, on the phylotype level, the esophagus represents a distinct ecological niche as only here the aerotolerant anaerobe L. murinus was detected (Figure 5). In contrast, L. gasseri/taiwanensis and also L. reuteri were present in the forestomach to the ileum but were missing in the esophagus (Figure 4). Generally, the preferred habitat for L. gasseri/taiwanensis and L. reuteri is the stomach (Figure 4). Particularly for L. reuteri it was well documented that the adaptation to the stomach is also accompanied by a host specialization; for example, rodent-specific genes were inactivated in L. reuteri strains from different vertebrate hosts [54]. As a consequence, the ability to form epithelial biofilms in the murine forestomach is strictly dependent on the strain's host origin [55]. Probably a similar specialization of L. murinus occurred to the esophageal epithelial cells (Figure 4). Of note, in a gnotobiotic mouse model colonized with eight strains of the altered Schaedler flora, the spatial distribution of L. murinus was very different from that presented here [56]. L. murinus was again present in the esophagus and absent in the non-glandular forestomach, but it declined again in the stomach until the ascending colon [56]. This clearly outlines the extreme sensibility of the microbial ecosystem and the enormous influence of the other members of the bacterial community.

\subsubsection{The Lower Alimentary Tract}

Generally, the terminal ileum seems to be a major demarcation concerning microaerobic (Lactobacillus) in the small intestine and anaerobic genera in the large intestine, starting with the caecum (lower alimentary tract). There is also a step up in the richness (amount of different phylotypes) between the terminal ileum and the caecum (Figure 1). Starting with the caecum, obligate anaerobic bacteria are present nearly exclusively indicating that here there is no selection pressure anymore to tolerate oxygen in the atmosphere. Thus, the severe loss of oxygen distally of the terminal ileum (anaerobic environment in the caecum and colon) seems to be a major checkpoint for the selection of the bacterial microbiota. Furthermore, in both the wild-type and Tff3 ${ }^{\mathrm{KO}}$ mice, there is a highly significant difference between the bacterial communities in the ascending colon and the transverse colon (Figures 2 and 3). For example, unclassified Bacteroidales and unclassified Bacteroidetes increase distally to the ascending colon, whereas unclassified Clostridiales decrease and Mucispirillum is strongly reduced. Thus, the caecum and the ascending colon represent a location with a special bacterial community when compared with the adjacent proximal and distal regions.

The characteristic bacterial communities in the caecum and the ascending colon are probably the result of an adaptation to the special physiological function and biochemical reactions typical of the lower alimentary tract, as well as certain anatomical features. Typically, in the proximal part of the large intestine, microbial degradation of special polysaccharides occurs (e.g., resistant starch), and it was compared with a bioreactor [57]. In humans, dietary plant fibers, which are composed of complex cell wall polysaccharides, are resistant to digestion and resorption in the small intestine [58]. For their breakdown, microbial fermentation in the large intestine is essential and this process provides about $10 \%$ of the human diet's energy. Major end products of this fermentation are short-chain fatty acids, i.e., acetate, propionate, and butyrate; the latter being a major energy source for colonocytes [58].

In contrast, the distal colon functions as a segregation device [57]. Here, water and electrolytes are resorbed, the feces shrink and form pellets, which are covered by a mucus layer (mainly Muc2) [59]. The major form of Muc2 is produced by the proximal colon, 
which encapsulates the fecal pellets; then a minor form of Muc2 derived from the distal colon leads to a secondary encapsulation $[23,24]$.

The transition from the small to the large intestine is also accompanied by severe histological changes as the villi are only present in the small intestine as well as the Paneth cells [60]. Furthermore, the ascending colon contains transverse folds that mimic human intestinal folds $[59,61,62]$.

The mucus probably plays a key role in microbial colonization of the gastrointestinal mucosa. The rodent stomach and large intestine were described to be covered by a twolayered mucus structure, i.e., a firmly attached, stratified inner layer and a loose outer layer; whereas the small intestine contains only a loose single mucus layer [21]. An inner layer was described in both the proximal and distal colon, but it appeared thicker in the distal part [62] The inner mucus layer of the murine colon, (probably the distal part [62]), was reported to be devoid of bacteria [63]. However, earlier studies by Swidsinski et al. already reported striking differences between the proximal and distal murine colon [57,64]. They clearly showed that bacteria had direct epithelial contact within the crypts of the proximal colon, but were separated from the distal colonic epithelium; in the latter, no microbiota was detected in the colonic crypts $[57,64]$. Thus, the mucus in the proximal colon is probably penetrable by bacteria [57]. This view is in line with the model that in the distal colon the bacterial microbiota is confined to the mucus layer of the fecal pellets and thus does not reach the epithelial surface [59]. As a consequence, the empty distal colon is devoid of bacteria [59]. In contrast, in the proximal colon, there is a close contact of the bacterial microbiota with the epithelium in spite of a mucus layer [59].

The intestinal mucus is a secretory product of GCs and MUC2 is the predominant gelforming mucin. However, intestinal GCs are not a uniform cell population, but they differ at various locations and fulfill different functions. As a hallmark of the colon, rare "sentinel" GCs (senGCs) were identified exclusively at the upper-crypt region, which respond to ligation of specific TLRs, such as TLR2/1,4, and 5, with inflammasome activation, exocytosis of Muc2, and expulsion of the activated senGCs [65]. Of note, the regional mucosa-associated microbiota determines the expression of TLR2 and TLR4 in the colon and TLR2 is typical of the proximal colon, whereas TLR4 is highest in the distal colon [66]. Thus, there is a reciprocal interaction between microbiota and MUC2 expression. These senGCs are gatekeepers of colonic crypts and they are metabolically linked to other GCs by gap junctions, which allows induction of MUC2 secretion from adjacent GCs [65]. Such a mechanism flushes bacteria away from crypt openings [65]. Furthermore, at least the distal colon contains another sub-population of GCs, i.e., proliferative, non-canonical, and canonical GCs in the crypts as well as "intercrypt" GCs (icGCs) between the crypts [47]. The latter seems to represent fully differentiated canonical GCs [47]. Of special note, canonical GCs in the crypts and icGCs secrete a different mucus; the intercrypt mucus is more permeable to bacteria when compared with the crypt mucus, which seals the crypts by a plume [47]. The two different mucus types can also be distinguished by their lectin binding patterns [47].

Taken together, the special bacterial community in the caecum and ascending colon is probably the result of an intimate relationship of the microbiota with its environment, i.e., the mucus and the luminal content (digesta region), respectively. Hallmarks in the caecum and ascending colon are the dramatic decrease in Lactobacillus, and the increase in Bacteroidetes (particularly Alistipes), Firmicutes (Lachnospiraceae, unclassified Ruminococcaceae, unclassified Clostridiales), and Deferribacteres (Mucispirillum). The latter, typically present in mice but not in humans [56], is found only within the mucus [67] and antagonizes Salmonella virulence in mice to protect against colitis [68]. However, Mucispirillum does not degrade mucins [69]. The area between the transverse folds of the ascending colon in close apposition to the colonic epithelium was reported to contain mainly Lachnospiraceae and Ruminococcaceae [70]. Thus, a model was proposed concerning the spatial organization of the microbiota across the radial axis of the ascending colon, i.e., large fusiform-shaped bacteria in the mucus (autochthonous/resident microbes), whereas 
rod- and coccoid-shaped bacteria are associated with the digesta (allochthonous/transient microbes) [61]. This concept was confirmed later for humans [71].

In the transverse and distal colon, particularly Bacteroidetes (unclassified Bacteroidales and unclassified Bacteroidetes) are enriched (Figures 2 and 3). This is an indication for intensive degradation of plant polysaccharides as more than $70 \%$ of genes encoding glycoside hydrolases belong to Bacteroidetes members [58].

\subsection{Comparison of Wild-Type Animals and Tff ${ }^{K O}$ Mice}

In addition to wild-type mice, here also the corresponding Tff ${ }^{\mathrm{KO}}$ mice were investigated as they show a high susceptibility in a DSS colitis model due to an intestinal barrier defect; whereas under normal conditions, the Tff $3^{\mathrm{KO}}$ mice do not show a specific phenotype $[29,30]$. After pairwise comparison of all the equivalent regions from wild-type and Tff3 $3^{\mathrm{KO}}$ animals, PERMANOVA revealed only a weak but significant difference at the genus level in the ascending colon only $(p=0.02)$, whereas all other anatomical locations did not show significant differences between the wild-type and Tff3 $3^{\mathrm{KO}}$ mice (data not shown).

This indicates that the presence of Tff 3 has no significant influence on the bacterial communities in most regions of the murine intestine. Tff3 is not of advantage or disadvantage for bacterial colonization of the intercrypt mucus. In contrast, Tff3 is obviously important for the protection of the host from bacterial infection during the condition of DSS-induced colitis [29]. Here, Tff3 could protect the sensitive stem cells at the base of the crypts. This hypothesis would be in line with the observation that Tff 3 is mainly expressed in the canonical GCs in the crypts, but not in icGCs (drastically reduced Tff $3 /$ Fcgbp ratio in the icGCs [47]). Furthermore, DSS treatment caused depletion of senGCs [65]. Thus, it could well be that Tff3 - due to its lectin activity - has a function for the viscosity of the protective crypt mucus plume. This assumption would be in line with the report that in humans, TFF3 is positively correlated with the viscoelastic properties of the cervical mucus plug [72].

Thus, in the future, it might be interesting to test whether there is a difference in the bacterial communities particularly within the crypts between wild-type and Tff ${ }^{\mathrm{KO}}$ mice during the condition of DSS colitis. In addition, an extension of this study to other microorganisms, such as viruses, fungi, archaea, and protists might detect possible differences between wild-type and Tff3 ${ }^{\mathrm{KO}}$ mice.

\subsection{Comparison of Gastrointestinal Bacterial Communities in Humans vs. Mice}

In the past, the bacterial microbiota was investigated in the human alimentary tract [28] considering biopsies from the gastric antrum and corpus, and the duodenum as belonging to the upper GI tract; whereas biopsies from the terminal ileum and ascending and descending colon were considered as part of the lower GI tract. In this study, we extended the regions, also considering the murine small intestine. We found that the bacterial communities in the murine small intestine are more similar to those in the human upper GI tract than to those in the human lower GI tract. Of note, the major colonizer in the human upper GI tract is Streptococcus; whereas in mice it is Lactobacillus, both belonging to the phylum Firmicutes. Regarding the lower GI tract, Bacteroidaceae and Lachnospiraceae dominated in both humans and mice (Figures 2 and 3). In humans, the data are limited by an endoscopic biopsy collection (particularly after the duodenum and before the terminal ileum), as well as potential bacterial cross-contamination.

\section{Materials and Methods}

\subsection{Murine Tissue}

Animal experiments were conducted in compliance with the Directive 2010/63/EU of the European parliament and of the council of 22 September 2010 on the protection of animals used for scientific purposes, the German Animal Welfare Act and the regulations on the welfare of animals used for experiments or for other scientific purposes in their currently 
valid versions. Tff3 ${ }^{\mathrm{KO}}$ and corresponding wild-type mice (mixed 129/Sv and C57BL/6 background) were bred from heterozygous littermates as described previously [73].

The animals were kept in standard cages (IVC Typ II) at the animal facility of the Medical Faculty of the Otto-von-Guericke University Magdeburg under specific-pathogenfree (spf) conditions in a regular $12 \mathrm{~h}$ dark-light cycle, maintaining controlled humidity (55 $\pm 10 \%)$ and temperature $\left(22 \pm 2{ }^{\circ} \mathrm{C}\right)$ with 15 - to 18 -fold air exchange rates. Rodent chow diet (ssniff ${ }^{\circledR} \mathrm{R} / \mathrm{M}-\mathrm{H}$; ssniff Spezialdiäten $\mathrm{GmbH}$, Soest, Germany; gamma-irradiated or autoclaved) and UV-irradiated tap water were provided ad libitum. The animals were not starved before the investigations. Animal care and experimental procedures were performed according to legal regulations (license number: IMMC-TWZ-01). The 12-weekold male mice (9 Tff3 ${ }^{K O}$ animals, weight 19.8-30.6 g; 9 WT animals, weight 22.6-31.4 g) were euthanized by isoflurane inhalation (overdose) and subsequent cervical dislocation.

Samples (stomach: about $0.5 \mathrm{~cm}$ in length; all other regions: $1.0-1.5 \mathrm{~cm}$ ) were taken from 13 regions of the GI tract: esophagus (total); forestomach, gastric corpus, gastric antrum; proximal and distal parts of the duodenum, respectively; middle section of the jejunum, distal ileum, middle part of the caecum; proximal (ascending), medial (transverse) and distal (descending) colon, and rectum. Samples were dissected including the luminal content, immediately frozen in liquid nitrogen and stored at $-80^{\circ} \mathrm{C}$.

\subsection{DNA Extraction and Library Construction}

In the first step, samples were suspended in $1 \mathrm{~mL}$ of lysis buffer, composed of $100 \mathrm{mM}$ Tris- $\mathrm{HCl} \mathrm{pH} 8.0,100 \mathrm{mM}$ EDTA, $100 \mathrm{mM} \mathrm{NaCl}, 1 \%(w / v)$ polyvinylpyrrolidone and $2 \%$ $(w / v)$ sodium dodecyl sulfate, transferred to a $2 \mathrm{~mL}$ Lysing Matrix E tube (Qbiogene, Alexis Biochemicals, Carlsbad, CA, USA), subjected to mechanical lysis in a FastPrep ${ }^{\circledR}$ -24 Instrument (MP Biomedicals, Santa Ana, CA, USA) for $40 \mathrm{~s}$ and $6.0 \mathrm{~m} \mathrm{~s}^{-1}$, and purified as described [74]. Then, genomic DNA was extracted essentially as previously described [74]. In the final step, amplicon libraries for sequencing were generated as previously described [75], where the V1-V2 region of the 16S rRNA gene was amplified after 20 PCR cycles using 27F and 338R primers [75] and sequenced on a MiSeq $(2 \times 300 \mathrm{bp}$, illumina, Hayward, CA, USA).

\subsection{Bioinformatic and Statistical Analysis}

All the fastQ files were analyzed using dada2 package [76] and a unique table containing all samples with the sequence reads and relative abundances was generated. Samples that did not reach 3000 reads ( 35 samples) were not considered for downstream analysis. Overall, 5,976,799 paired-ends reads were obtained with a mean of 30,339 $\pm 15,548$ reads per sample. Samples with more than 3000 reads (197 samples) were resampled to the minimum sequencing depth of 3172 reads per sample using the phyloseq package [77] returning 4560 phylotypes. The phylotypes were taxonomically annotated using the ribosomal data project based on the naïve Bayesian classification [78] with a pseudo-bootstrap threshold of $80 \%$. Relevant phylotypes were manually annotated until species using NCBI database and the name of species were given if the sequence was identical to the sequence of the correspondent type strain deposited in the database. The vegan package (version 4.0.4) was used to generate the rarefaction curves as well as the phylotypes richness and the Simpson index $(1-\lambda)$, where $\lambda=\Sigma \mathrm{p}_{\mathrm{i}}{ }^{2}$. Relative abundances (in percentage) of phylotypes and genera were used for downstream analyses. Significant differences between locations (esophagus, forestomach, gastric corpus, gastric antrum, proximal and distal parts of the duodenum, respectively, middle section of the jejunum, distal ileum, middle part of the caecum, proximal/ascending, medial/transverse and distal/descending colon, and rectum) were evaluated using permutational multivariate analysis of variance (PERMANOVA) in Past4. Significant differences in the relative abundances between regions were assessed using Mann-Whitney test with Benjamini-Hochberg correction in Prim 7 (GraphPad Software). $\mathrm{P}$ values were considered significant if $p<0.05\left(p<0.05\right.$ : significant, ${ }^{*} ; p<0.01$ : highly significant, ${ }^{* *} ; p<0.001$ : extremely high significant, $\left.{ }^{* * *}\right)$. Dendrogram was generated 
using the data matrix, comprising 4560 phylotypes, after the calculation of sample similarity using the Bray-Curtis algorithm.

\section{Conclusions}

In this study, we systematically analyzed the bacterial communities throughout the entire murine gastrointestinal tract. We observed a clear trend in microbiome alterations from the upper, through the middle and through the lower GI tract with its unique microbial composition. The microbial similarity between wild-type and $T f f 3^{\mathrm{KO}}$ mice questions the role of genetics in defining microbial niches under normal conditions. Defined knowledge on microbial trends in the GI tract is crucial for understanding the functional interaction between gut microbes and the host and could prove helpful for further investigations using mouse models. Future systematic studies are needed to address the bacterial microbiota, particularly under the conditions of specific infections, e.g., with Helicobacter pylori, or DSS-induced colitis.

Supplementary Materials: The following are available online at https:/ /www.mdpi.com/article/10 .3390/ijms23031783/s1.

Author Contributions: Conceptualization, W.H.; wild-type and Tff ${ }^{\mathrm{KO}}$ mice breeding management, genotyping and collection of murine specimens, F.S., E.B.Z. and K.H.; sequencing, R.V.-V., D.S. and M.Z.; statistical analysis, R.V.-V.; data curation, R.V.-V.; writing—original draft preparation, R.V.-V. and W.H.; writing-review and editing, F.S., E.B.Z., K.H., D.S., M.Z. and A.L.; visualization, R.V.-V.; funding acquisition, A.L. All authors have read and agreed to the published version of the manuscript.

Funding: A.L. and R.V.-V. were funded by the European Commission through the "European Funds for Regional Development" (EFRE) as well as the Ministry of Economy, Science and Digitalization of Saxony-Anhalt as part of the research program "Autonomy in old age" ("LiLife" Project ID: ZS/2018/11/95324).

Institutional Review Board Statement: The study was approved by the Animal Welfare Officer of the Medical Faculty of the Otto-von-Guericke University Magdeburg (license number: IMMC-TWZ-01, 1 January 2015).

Informed Consent Statement: Not applicable.

Data Availability Statement: The data presented in this study are available in Supplementary Table S1.

Acknowledgments: We thank Ilka Kramer and Cosima Thon (Otto-von-Guericke University, Magdeburg) for their technical support in sequencing, and Jonathan A. Lindquist (Otto-von-Guericke University, Magdeburg) for his valuable comments on the manuscript.

Conflicts of Interest: The authors declare no conflict of interest. The funders had no role in the design of the study; in the collection, analyses, or interpretation of data; in the writing of the manuscript, or in the decision to publish the results.
Abbreviations
DSS Dextran sulfate sodium
FCGBP IgG Fc binding protein
GC Goblet cell
GI gastrointestinal
icGC Intercrypt goblet cell
senGC Sentinel goblet cell
TFF Trefoil factor family
TLR Toll-like receptor 


\section{References}

1. Spor, A.; Koren, O.; Ley, R. Unravelling the effects of the environment and host genotype on the gut microbiome. Nat. Rev. Microbiol. 2011, 9, 279-290. [CrossRef]

2. Integrative, H.M.P.; Proctor, L.M.; Creasy, H.H.; Fettweis, J.M.; Lloyd-Price, J.; Mahurkar, A.; Zhou, W.; Buck, G.A.; Snyder, M.P.; Strauss, J.F., III; et al. The Integrative Human Microbiome Project. Nature 2019, 569, 641-648. [CrossRef]

3. Kau, A.L.; Ahern, P.P.; Griffin, N.W.; Goodman, A.L.; Gordon, J.I. Human nutrition, the gut microbiome and the immune system. Nature 2011, 474, 327-336. [CrossRef]

4. Tilg, H.; Moschen, A.R. Food, immunity, and the microbiome. Gastroenterology 2015, 148, 1107-1119. [CrossRef]

5. Gentile, C.L.; Weir, T.L. The gut microbiota at the intersection of diet and human health. Science 2018, 362, 776-780. [CrossRef]

6. Pothuraju, R.; Chaudhary, S.; Rachagani, S.; Kaur, S.; Roy, H.K.; Bouvet, M.; Batra, S.K. Mucins, gut microbiota, and postbiotics role in colorectal cancer. Gut Microbes 2021, 13, 1974795. [CrossRef]

7. Ley, R.E.; Turnbaugh, P.J.; Klein, S.; Gordon, J.I. Microbial ecology: Human gut microbes associated with obesity. Nature 2006, 444, 1022-1023. [CrossRef]

8. Tilg, H.; Kaser, A. Gut microbiome, obesity, and metabolic dysfunction. J. Clin. Investig. 2011, 121, 2126-2132. [CrossRef]

9. Hirschberg, S.; Gisevius, B.; Duscha, A.; Haghikia, A. Implications of Diet and The Gut Microbiome in Neuroinflammatory and Neurodegenerative Diseases. Int. J. Mol. Sci. 2019, 20, 3109. [CrossRef]

10. Arthur, J.C.; Perez-Chanona, E.; Mühlbauer, M.; Tomkovich, S.; Uronis, J.M.; Fan, T.-J.; Campbell, B.J.; Abujamel, T.; Dogan, B.; Rogers, A.B.; et al. Intestinal inflammation targets cancer-inducing activity of the microbiota. Science 2012, 338, 120-123. [CrossRef]

11. Boccellato, F.; Meyer, T.F. Bacteria Moving into Focus of Human Cancer. Cell Host Microbe 2015, 17, 728-730. [CrossRef]

12. Wargo, J.A. Modulating gut microbes. Science 2020, 369, 1302-1303. [CrossRef]

13. Yang, I.; Nell, S.; Suerbaum, S. Survival in hostile territory: The microbiota of the stomach. FEMS Microbiol. Rev. 2013, 37, 736-761. [CrossRef]

14. Nardone, G.; Compare, D. The human gastric microbiota: Is it time to rethink the pathogenesis of stomach diseases? United Eur. Gastroenterol. J. 2015, 3, 255-260. [CrossRef]

15. Ley, R.E.; Peterson, D.A.; Gordon, J.I. Ecological and evolutionary forces shaping microbial diversity in the human intestine. Cell 2006, 124, 837-848. [CrossRef]

16. Mahowald, M.A.; Rey, F.E.; Seedorf, H.; Turnbaugh, P.J.; Fulton, R.S.; Wollam, A.; Shah, N.; Wang, C.; Magrini, V.; Wilson, R.K.; et al. Characterizing a model human gut microbiota composed of members of its two dominant bacterial phyla. Proc. Natl. Acad. Sci. USA 2009, 106, 5859-5864. [CrossRef]

17. McGuckin, M.A.; Lindén, S.K.; Sutton, P.; Florin, T.H. Mucin dynamics and enteric pathogens. Nat. Rev. Microbiol. 2011, 9, 265-278. [CrossRef]

18. Johansson, M.E.V.; Sjövall, H.; Hansson, G.C. The gastrointestinal mucus system in health and disease. Nat. Rev. Gastroenterol. Hepatol. 2013, 10, 352-361. [CrossRef]

19. Duncan, K.; Carey-Ewend, K.; Vaishnava, S. Spatial analysis of gut microbiome reveals a distinct ecological niche associated with the mucus layer. Gut Microbes 2021, 13, 1874815. [CrossRef]

20. Hoffmann, W. TFF2, a MUC6-binding lectin stabilizing the gastric mucus barrier and more. Int. J. Oncol. 2015, 47, 806-816. [CrossRef]

21. Johansson, M.E.V.; Larsson, J.M.H.; Hansson, G.C. The two mucus layers of colon are organized by the MUC2 mucin, whereas the outer layer is a legislator of host-microbial interactions. Proc. Natl. Acad. Sci. USA 2011, 108, 4659-4665. [CrossRef] [PubMed]

22. Pelaseyed, T.; Bergström, J.H.; Gustafsson, J.K.; Ermund, A.; Birchenough, G.M.H.; Schütte, A.; van der Post, S.; Svensson, F.; Rodríguez-Piñeiro, A.M.; Nyström, E.E.L.; et al. The mucus and mucins of the goblet cells and enterocytes provide the first defense line of the gastrointestinal tract and interact with the immune system. Immunol. Rev. 2014, 260, 8-20. [CrossRef] [PubMed]

23. Bergstrom, K.; Shan, X.; Casero, D.; Batushansky, A.; Lagishetty, V.; Jacobs, J.P.; Hoover, C.; Kondo, Y.; Shao, B.; Gao, L.; et al. Proximal colon-derived O-glycosylated mucus encapsulates and modulates the microbiota. Science 2020, 370, 467-472. [CrossRef] [PubMed]

24. Birchenough, G.M.H.; Johansson, M.E.V. Forming a mucus barrier along the colon. Science 2020, 370, 402-403. [CrossRef]

25. Bäckhed, F.; Ding, H.; Wang, T.; Hooper, L.V.; Koh, G.Y.; Nagy, A.; Semenkovich, C.F.; Gordon, J.I. The gut microbiota as an environmental factor that regulates fat storage. Proc. Natl. Acad. Sci. USA 2004, 101, 15718-15723. [CrossRef] [PubMed]

26. Chu, C.; Murdock, M.H.; Jing, D.; Won, T.H.; Chung, H.; Kressel, A.M.; Tsaava, T.; Addorisio, M.E.; Putzel, G.G.; Zhou, L.; et al. The microbiota regulate neuronal function and fear extinction learning. Nature 2019, 574, 543-548. [CrossRef]

27. Muller, P.A.; Matheis, F.; Schneeberger, M.; Kerner, Z.; Jové, V.; Mucida, D. Microbiota-modulated CART(+) enteric neurons autonomously regulate blood glucose. Science 2020, 370, 314-321. [CrossRef]

28. Vasapolli, R.; Schütte, K.; Schulz, C.; Vital, M.; Schomburg, D.; Pieper, D.H.; Vilchez-Vargas, R.; Malfertheiner, P. Analysis of Transcriptionally Active Bacteria Throughout the Gastrointestinal Tract of Healthy Individuals. Gastroenterology 2019, 157, 1081-1092.e3. [CrossRef]

29. Mashimo, H.; Wu, D.C.; Podolsky, D.K.; Fishman, M.C. Impaired defense of intestinal mucosa in mice lacking intestinal trefoil factor. Science 1996, 274, 262-265. [CrossRef] 
30. Hoffmann, W. Trefoil Factor Family (TFF) Peptides and Their Links to Inflammation: A Re-evaluation and New Medical Perspectives. Int. J. Mol. Sci. 2021, 22, 4909. [CrossRef]

31. Johansson, M.E.V.; Gustafsson, J.K.; Sjöberg, K.E.; Petersson, J.; Holm, L.; Sjövall, H.; Hansson, G.C. Bacteria penetrate the inner mucus layer before inflammation in the dextran sulfate colitis model. PLoS ONE 2010, 5, e12238. [CrossRef] [PubMed]

32. Hoffmann, W. Trefoil Factor Family (TFF) Peptides and Their Diverse Molecular Functions in Mucus Barrier Protection and More: Changing the Paradigm. Int. J. Mol. Sci. 2020, 21, 4535. [CrossRef]

33. Hoffmann, W. Trefoil Factor Family (TFF) Peptides. Encyclopedia 2021, 1, 74. [CrossRef]

34. Albert, T.K.; Laubinger, W.; Müller, S.; Hanisch, F.-G.; Kalinski, T.; Meyer, F.; Hoffmann, W. Human intestinal TFF3 forms disulfide-linked heteromers with the mucus-associated FCGBP protein and is released by hydrogen sulfide. J. Proteome Res. 2010, 9, 3108-3117. [CrossRef] [PubMed]

35. Houben, T.; Harder, S.; Schlüter, H.; Kalbacher, H.; Hoffmann, W. Different Forms of TFF3 in the Human Saliva: Heterodimerization with IgG Fc Binding Protein (FCGBP). Int. J. Mol. Sci. 2019, 20, 5000. [CrossRef]

36. Hauser, F.; Poulsom, R.; Chinery, R.; Rogers, L.A.; Hanby, A.M.; Wright, N.A.; Hoffmann, W. hP1.B, a human P-domain peptide homologous with rat intestinal trefoil factor, is expressed also in the ulcer-associated cell lineage and the uterus Proc. Natl. Acad. Sci. USA 1993, 90, 6961-6965. [CrossRef]

37. Harada, N.; Iijima, S.; Kobayashi, K.; Yoshida, T.; Brown, W.R.; Hibi, T.; Oshima, A.; Morikawa, M. Human IgGFc binding protein (FcgammaBP) in colonic epithelial cells exhibits mucin-like structure. J. Biol. Chem. 1997, 272, 15232-15241. [CrossRef]

38. Jagla, W.; Wiede, A.; Hinz, M.; Dietzmann, K.; Gülicher, D.; Gerlach, K.L.; Hoffmann, W. Secretion of TFF-peptides by human salivary glands. Cell Tissue Res. 1999, 298, 161-166. [CrossRef]

39. Kouznetsova, I.; Gerlach, K.L.; Zahl, C.; Hoffmann, W. Expression analysis of human salivary glands by laser microdissection: Differences between submandibular and labial glands. Cell. Physiol. Biochem. 2010, 26, 375-382. [CrossRef]

40. Kouznetsova, I.; Kalinski, T.; Peitz, U.; Mönkemüller, K.E.; Kalbacher, H.; Vieth, M.; Meyer, F.; Roessner, A.; Malfertheiner, P.; Lippert, H.; et al. Localization of TFF3 peptide in human esophageal submucosal glands and gastric cardia: Differentiation of two types of gastric pit cells along the rostro-caudal axis. Cell Tissue Res. 2007, 328, 365-374. [CrossRef]

41. Kobayashi, K.; Ogata, H.; Morikawa, M.; Iijima, S.; Harada, N.; Yoshida, T.; Brown, W.R.; Inoue, N.; Hamada, Y.; Ishii, H.; et al. Distribution and partial characterisation of IgG Fc binding protein in various mucin producing cells and body fluids. Gut 2002 51, 169-176. [CrossRef]

42. Kouznetsova, I.; Peitz, U.; Vieth, M.; Meyer, F.; Vestergaard, E.M.; Malfertheiner, P.; Roessner, A.; Lippert, H.; Hoffmann, W. A gradient of TFF3 (trefoil factor family 3) peptide synthesis within the normal human gastric mucosa. Cell Tissue Res. 2004, 316, 155-165. [CrossRef] [PubMed]

43. Znalesniak, E.B.; Salm, F.; Hoffmann, W. Molecular Alterations in the Stomach of Tff1-Deficient Mice: Early Steps in Antral Carcinogenesis. Int. J. Mol. Sci. 2020, 21, 644. [CrossRef]

44. Li, C.; Wang, R.; Su, B.; Luo, Y.; Terhune, J.; Beck, B.; Peatman, E. Evasion of mucosal defenses during Aeromonas hydrophila infection of channel catfish (Ictalurus punctatus) skin. Dev. Comp. Immunol. 2013, 39, 447-455. [CrossRef] [PubMed]

45. Hoffmann, W. Trefoil Factor Family (TFF) Peptides and their Different Roles in the Mucosal Innate Immune Defense and More: An Update. Curr. Med. Chem. 2021, 28, 7387-7399. [CrossRef]

46. Madsen, J.; Sorensen, G.L.; Nielsen, O.; Tornøe, I.; Thim, L.; Fenger, C.; Mollenhauer, J.; Holmskov, U. A variant form of the human deleted in malignant brain tumor 1 (DMBT1) gene shows increased expression in inflammatory bowel diseases and interacts with dimeric trefoil factor 3 (TFF3). PLoS ONE 2013, 8, e64441. [CrossRef]

47. Nyström, E.E.L.; Martinez-Abad, B.; Arike, L.; Birchenough, G.M.H.; Nonnecke, E.B.; Castillo, P.A.; Svensson, F.; Bevins, C.L.; Hansson, G.C.; Johansson, M.E.V. An intercrypt subpopulation of goblet cells is essential for colonic mucus barrier function. Science 2021, 372, eabb1590. [CrossRef] [PubMed]

48. Bathum Nexoe, A.; Pedersen, A.A.; von Huth, S.; Detlefsen, S.; Hansen, P.L.; Holmskov, U. Immunohistochemical Localization of Deleted in Malignant Brain Tumors 1 in Normal Human Tissues. J. Histochem. Cytochem. 2020, 68, 377-387. [CrossRef] [PubMed]

49. Prakobphol, A.; Xu, F.; Hoang, V.M.; Larsson, T.; Bergstrom, J.; Johansson, I.; Frängsmyr, L.; Holmskov, U.; Leffler, H.; Nilsson, C.; et al. Salivary agglutinin, which binds Streptococcus mutans and Helicobacter pylori, is the lung scavenger receptor cysteine-rich protein gp-340. J. Biol. Chem. 2000, 275, 39860-39866. [CrossRef]

50. Khoder, G.; Al-Yassir, F.; Al Menhali, A.; Saseedharan, P.; Sugathan, S.; Tomasetto, C.; Karam, S.M. Probiotics Upregulate Trefoil Factors and Downregulate Pepsinogen in the Mouse Stomach. Int. J. Mol. Sci. 2019, 20, 3901. [CrossRef]

51. Bergstrom, K.S.B.; Guttman, J.A.; Rumi, M.; Ma, C.; Bouzari, S.; Khan, M.A.; Gibson, D.L.; Vogl, A.W.; Vallance, B.A. Modulation of intestinal goblet cell function during infection by an attaching and effacing bacterial pathogen. Infect. Immun. 2008, 76, 796-811. [CrossRef] [PubMed]

52. Shalapour, S.; Deiser, K.; Kühl, A.A.; Glauben, R.; Krug, S.M.; Fischer, A.; Sercan, O.; Chappaz, S.; Bereswill, S.; Heimesaat, M.M.; et al. Interleukin-7 links T lymphocyte and intestinal epithelial cell homeostasis. PLoS ONE 2012, 7, e31939. [CrossRef] [PubMed]

53. Podolsky, D.K.; Gerken, G.; Eyking, A.; Cario, E. Colitis-associated variant of TLR2 causes impaired mucosal repair because of TFF3 deficiency. Gastroenterology 2009, 137, 209-220. [CrossRef] [PubMed]

54. Frese, S.A.; Benson, A.K.; Tannock, G.W.; Loach, D.M.; Kim, J.; Zhang, M.; Oh, P.L.; Heng, N.C.K.; Patil, P.B.; Juge, N.; et al. The evolution of host specialization in the vertebrate gut symbiont Lactobacillus reuteri. PLoS Genet. 2011, 7, e1001314. [CrossRef] 
55. Frese, S.A.; Mackenzie, D.A.; Peterson, D.A.; Schmaltz, R.; Fangman, T.; Zhou, Y.; Zhang, C.; Benson, A.K.; Cody, L.A.; Mulholland, F.; et al. Molecular characterization of host-specific biofilm formation in a vertebrate gut symbiont. PLoS Genet. 2013, 9, e1004057. [CrossRef]

56. Sarma-Rupavtarm, R.B.; Ge, Z.; Schauer, D.B.; Fox, J.G.; Polz, M.F. Spatial distribution and stability of the eight microbial species of the altered schaedler flora in the mouse gastrointestinal tract. Appl. Environ. Microbiol. 2004, 70, 2791-2800. [CrossRef]

57. Swidsinski, A.; Loening-Baucke, V.; Lochs, H.; Hale, L.-P. Spatial organization of bacterial flora in normal and inflamed intestine: A fluorescence in situ hybridization study in mice. World J. Gastroenterol. 2005, 11, 1131-1140. [CrossRef]

58. El Kaoutari, A.; Armougom, F.; Gordon, J.I.; Raoult, D.; Henrissat, B. The abundance and variety of carbohydrate-active enzymes in the human gut microbiota. Nat. Rev. Microbiol. 2013, 11, 497-504. [CrossRef]

59. Kamphuis, J.B.J.; Mercier-Bonin, M.; Eutamène, H.; Theodorou, V. Mucus organisation is shaped by colonic content; a new view. Sci. Rep. 2017, 7, 8527. [CrossRef]

60. Parikh, K.; Antanaviciute, A.; Fawkner-Corbett, D.; Jagielowicz, M.; Aulicino, A.; Lagerholm, C.; Davis, S.; Kinchen, J.; Chen, H.H.; Alham, N.K.; et al. Colonic epithelial cell diversity in health and inflammatory bowel disease. Nature 2019, 567, 49-55. [CrossRef]

61. Nava, G.M.; Stappenbeck, T.S. Diversity of the autochthonous colonic microbiota. Gut Microbes 2011, 2, 99-104. [CrossRef] [PubMed]

62. Ermund, A.; Schütte, A.; Johansson, M.E.V.; Gustafsson, J.K.; Hansson, G.C. Studies of mucus in mouse stomach, small intestine, and colon. I. Gastrointestinal mucus layers have different properties depending on location as well as over the Peyer's patches. Am. J. Physiol. Gastrointest. Liver Physiol. 2013, 305, G341-G347. [CrossRef] [PubMed]

63. Johansson, M.E.V.; Phillipson, M.; Petersson, J.; Velcich, A.; Holm, L.; Hansson, G.C. The inner of the two Muc2 mucin-dependent mucus layers in colon is devoid of bacteria. Proc. Natl. Acad. Sci. USA 2008, 105, 15064-15069. [CrossRef] [PubMed]

64. Swidsinski, A.; Sydora, B.C.; Doerffel, Y.; Loening-Baucke, V.; Vaneechoutte, M.; Lupicki, M.; Scholze, J.; Lochs, H.; Dieleman, L.A Viscosity gradient within the mucus layer determines the mucosal barrier function and the spatial organization of the intestinal microbiota. Inflamm. Bowel Dis. 2007, 13, 963-970. [CrossRef]

65. Birchenough, G.M.H.; Nyström, E.E.L.; Johansson, M.E.V.; Hansson, G.C. A sentinel goblet cell guards the colonic crypt by triggering Nlrp6-dependent Muc2 secretion. Science 2016, 352, 1535-1542. [CrossRef]

66. Wang, Y.; Devkota, S.; Musch, M.W.; Jabri, B.; Nagler, C.; Antonopoulos, D.A.; Chervonsky, A.; Chang, E.B. Regional mucosa-associated microbiota determine physiological expression of TLR2 and TLR4 in murine colon. PLoS ONE 2010, 5, e13607. [CrossRef]

67. Li, H.; Limenitakis, J.P.; Fuhrer, T.; Geuking, M.B.; Lawson, M.A.; Wyss, M.; Brugiroux, S.; Keller, I.; Macpherson, J.A.; Rupp, S.; et al. The outer mucus layer hosts a distinct intestinal microbial niche. Nat. Commun. 2015, 6, 8292. [CrossRef]

68. Herp, S.; Brugiroux, S.; Garzetti, D.; Ring, D.; Jochum, L.M.; Beutler, M.; Eberl, C.; Hussain, S.; Walter, S.; Gerlach, R.G.; et al. Mucispirillum schaedleri Antagonizes Salmonella Virulence to Protect Mice against Colitis. Cell Host Microbe 2019, 25, 681694.e8. [CrossRef]

69. Loy, A.; Pfann, C.; Steinberger, M.; Hanson, B.; Herp, S.; Brugiroux, S.; Gomes Neto, J.C.; Boekschoten, M.V.; Schwab, C.; Urich, T.; et al. Lifestyle and Horizontal Gene Transfer-Mediated Evolution of Mucispirillum schaedleri, a Core Member of the Murine Gut Microbiota. mSystems 2017, 2, e00171-16. [CrossRef]

70. Nava, G.M.; Friedrichsen, H.J.; Stappenbeck, T.S. Spatial organization of intestinal microbiota in the mouse ascending colon. ISME J. 2011, 5, 627-638. [CrossRef]

71. Ringel, Y.; Maharshak, N.; Ringel-Kulka, T.; Wolber, E.A.; Sartor, R.B.; Carroll, I.M. High throughput sequencing reveals distinct microbial populations within the mucosal and luminal niches in healthy individuals. Gut Microbes 2015, 6, 173181. [CrossRef] [PubMed]

72. Bastholm, S.K.; Samson, M.H.; Becher, N.; Hansen, L.K.; Stubbe, P.R.; Chronakis, I.S.; Nexo, E.; Uldbjerg, N. Trefoil factor peptide 3 is positively correlated with the viscoelastic properties of the cervical mucus plug. Acta Obstet. Gynecol. Scand. 2017, 96, 47-52. [CrossRef] [PubMed]

73. Fu, T.; Znalesniak, E.B.; Kalinski, T.; Möhle, L.; Biswas, A.; Salm, F.; Dunay, I.R.; Hoffmann, W. TFF Peptides Play a Role in the Immune Response Following Oral Infection of Mice with Toxoplasma gondii. Eur. J. Microbiol. Immunol. 2015, 5, $221-231$. [CrossRef] [PubMed]

74. Vilchez-Vargas, R.; Geffers, R.; Suárez-Diez, M.; Conte, I.; Waliczek, A.; Kaser, V.S.; Kralova, M.; Junca, H.; Pieper, D.H. Analysis of the microbial gene landscape and transcriptome for aromatic pollutants and alkane degradation using a novel internally calibrated microarray system. Environ. Microbiol. 2013, 15, 1016-1039. [CrossRef] [PubMed]

75. Rath, S.; Heidrich, B.; Pieper, D.H.; Vital, M. Uncovering the trimethylamine-producing bacteria of the human gut microbiota. Microbiome 2017, 5, 54. [CrossRef]

76. Callahan, B.J.; McMurdie, P.J.; Rosen, M.J.; Han, A.W.; Johnson, A.J.A.; Holmes, S.P. DADA2: High-resolution sample inference from Illumina amplicon data. Nat. Methods 2016, 13, 581-583. [CrossRef]

77. McMurdie, P.J.; Holmes, S. phyloseq: An R package for reproducible interactive analysis and graphics of microbiome census data. PLoS ONE 2013, 8, e61217. [CrossRef]

78. Wang, Q.; Garrity, G.M.; Tiedje, J.M.; Cole, J.R. Naive Bayesian classifier for rapid assignment of rRNA sequences into the new bacterial taxonomy. Appl. Environ. Microbiol. 2007, 73, 5261-5267. [CrossRef] 